\title{
SYNTHESIS, CHARACTERIZATION AND CYTOTOXICITY EVALUATION OF MAGNETIC NANOSILICA IN L929 CELL LINE ${ }^{1}$
}

\author{
SÍNTESE, CARACTERIZAÇÃO E AVALIAÇÃO DA CITOTOXICIDADE DA \\ NANOSÍLICA MAGNÉTICA EM LINHAGEM CELULAR L929
}

\section{Franciele da Silva Bruckmann², Amanda Carolina Pimentel'2, Altevir Rossato Viana ${ }^{3}$, Theodoro da Rosa Salles ${ }^{4}$, Luciana Maria Fontanari Krause ${ }^{5}$, Sérgio Roberto Mortari ${ }^{5}$, Ivana Zanella da Silva ${ }^{5}$ e Cristiano Rodrigo Bohn Rhoden ${ }^{6}$}

\begin{abstract}
Recently, the incorporation of magnetic nanoparticles in nanomaterials has been showning to be very efficient, which leads to several scientific studies being carried out. Magnetic silica nanoparticles have excellent properties, enabling application in different fields including nanoscience. In this context, this work aimed to synthesize and characterize nanosilica with magnetic properties, in order to evaluate of the cytotoxicity in L929 cell line. The methodology for incorporation of magnetic nanoparticles proved to be fast and effective for obtaining

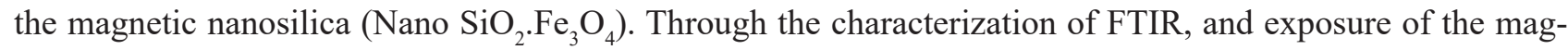
netic field it was possible to verify the incorporation of ferrite in the nanosilica, as well as the XRD technique, the reduction of the particle size and the degree of crystallinity was evidenced. It was possible to verify that the synthesized nano $\mathrm{SiO}_{2} \cdot \mathrm{Fe}_{3} \mathrm{O}_{4}$ showed to be safe in the treatments with lower concentrations with less amount of incoporated ferrite. Nevertheless, more characterizations and studies will be developed to determine the safety and therapeutic efficacy of this magnetic nanoparticles.
\end{abstract}

Keywords: Cytotoxic activity, Magnetic nanoparticles; Ferrite.

\section{RESUMO}

Recentemente a incorporação de nanopartículas magnéticas em nanomateriais têm se mostrado bastante eficiente, o que faz com que diversos estudos sejam realizados. As nanopartículas de sílica magnéticas apresentam excelentes propriedades, possibilitando o emprego em diferentes campos que contemplam a nanociência. Nesse contexto, este trabalho teve como objetivo sintetizar a nanosílica com propriedades magnéticas, caracterizar e avaliar sua citotoxicidade em linhagem celular L929. O uso da metodologia para a incorporação de nanopartículas magnéticas mostrou-se rápida e eficaz para a obtenção da nanosílica magnética (Nano $\mathrm{SiO}_{2} \cdot \mathrm{Fe}_{3} \mathrm{O}_{4}$ ). Mediante a caracterização por FTIR, e a exposição a um campo magnético foi possivel verificar a incorporação de ferrita na nanosílica, bem como, através da técnica de DRX, a diminuição do tamanho de partícula e o grau de cristalinidade foram observados. Pelos ensaios realizados foi possivel

\footnotetext{
${ }^{1}$ Study developed at the Nanoscience Posgraduate Program.

${ }^{2}$ MsD student at the Nanoscience Posgraduate Program - Universidade Franciscana (UFN). E-mail: francielebruckmann2@ gmail.com, amandacarolinapimentel@gmail.com

${ }^{3}$ PhD student at the Nanoscience Posgraduate Program - Universidade Franciscana (UFN). E-mail: rossato.viana@ hotmail.com

${ }^{4}$ Graduation student - Universidade Franciscana (UFN). E-mail: theodoro.rsalles@gmail.com

${ }^{5}$ Colaborators - Nanoscience Posgraduate Program -Universidade Franciscana (UFN). E-mails: Ifontanari@yahoo.com.br; mortari@ufn.edu.br; ivana.zanella@gmail.com

${ }^{6}$ Correspondent Autor - Nanoscience Posgraduate Program - Universidade Franciscana (UFN). E-mail: cristianorbr@ gmail.com
} 
auferir que a nano $\mathrm{SiO}_{2} . \mathrm{Fe}_{3} \mathrm{O}_{4}$ mostrou-se segura nos tratamentos em baixas concentrações e com menor quantidade de ferrita incorporada. Não obstante, novas caracterizações e novos estudos serão desenvolvidos para determinar a segurança e a eficácia terapêutica das nanopartículas.

Palavras-chave: Atividade citotóxica; nanopartículas magneticas, ferrita.

\section{INTRODUCTION}

Nanomaterials are substances that have at least one dimension in the order of 1-100 nanometers. Nanoscience, through the manipulation of substances, has important scientific principles in different areas that include its applications. In particular, pharmaceutical area has stood out for the development of new substances, such as the encapsulation of active compounds and vectorization of drugs (PINTO et al., 2017, VIANA et al., 2019). Among these compounds, siliceous nanoparticles have important characteristics for the development of compounds with biological applications, owing to the high surface area, size, morphology control, support capacity and structural modification (NABESHI et al., 2011; ZHANG et al., 2020).

Silica nanoparticles can easily be covered by metallic particles forming a core-shell nanoparticulate system (BARIK; SAHU; SWAIN, 2008). Recently, Li et al. (2011) synthesized silica microspheres coated with $\mathrm{Fe}_{3} \mathrm{O}_{4}$ to extract human DNA from whole blood samples, the process proved to be effective, fast, without needing organic solvents and centrifugation. Similarly, Beg et al. (2017) synthesized magnetic silica nanotubes as a doxorubicin nanocarrier and contrast agent. The studies developed have shown that the compound has excellent performance as a theranostic agent and in the direct delivery of drugs. In a recent study, Vo et al. (2019) synthesized a porous silica nanoparticle functionalized with gelatin as a nanoplatform for doxorubicin delivery. The obtained nanocarrier showed excellent capacity for the encapsulation of the active compound. Morever, by in vitro tests, it was possible to verify that the drug release occurs in a controlled manner and with a responsive $\mathrm{pH}$.

Janardan et al. (2016) synthesized silica nanoparticles by sol-gel method and hypercoordination process, where both compounds showed excellent antimicrobial properties against E. coli, S. aureus and B. subtilis strains. The literature has also reported the use of nanosilica in the synthesis of nanocomposites with application in tissue engineering. Madhumathi et al. (2009) used nanosilica to the production of scaffolds, through the tests performed, it was found that the material has excellent biocompatibility and stimulatory capacity for the synthesis of apatite.

Although nanosilica has important biological activity, some studies have shown that the nanoparticle is capable of generating reactive oxygen species (ROS), lactate dehydrogenase release (LDH) and cytokine production. However, toxicity is dependent on size, morphology, chosen cell line and concentration tests (NABESHI et al., 2011; YOSHIDA et al., 2011). Considering the numerous possibilities of application of nanosilica, this work aimed to synthesize and characterize nanosilica 
with magnetic properties with different proportions of incorporated ferrite, in order to evaluate the toxicity of L929 cells to determine the safe concentration for future biological applications.

\section{MATERIALS AND METHODS}

\section{PREPARATION OF NANOSILICA}

The synthesis of nanosilica was carried out according to the literature (ONG et al., 2019). The obtaining process was divided into three steps, that is acid leaching, calcination and top-down process to reduce the particle size.

\section{Acid leaching}

This step consisted of removing impurities contained in the rice husk by acid chemical treatment. Initially, $10 \mathrm{~g}$ of unprocessed rice husks were treated in $200 \mathrm{~mL}$ of a $0.5 \mathrm{~mol} / \mathrm{L}^{-1}$ hydrochloric acid solution (Synth®, 37\%) for 30-45 minutes under temperature of $60-80{ }^{\circ} \mathrm{C}$.

Then, system was mechanically stirred on a magnetic stirrer (Fisatom, model 752A) at 120 rpm (1 hour). Subsequently, the solution was filtered through (15 micrometers), the first effluent being discarded in a specific disposal container. In the remaining filtration steps, $1.5 \mathrm{~L}$ of preheated distilled water was added to adjust the $\mathrm{pH}$ to close to 7 . The silica obtained was dried in oven (DeLeo) at $80{ }^{\circ} \mathrm{C}$ for $24 \mathrm{~h}$.

\section{Calcination}

Approximately $8 \mathrm{~g}$ of the material was obtained and subjected to calcination in a muffle furnace (EDG, model EDG3P-S) at $600-700{ }^{\circ} \mathrm{C}$ for $4 \mathrm{~h}$, with a heating ramp of $30{ }^{\circ} \mathrm{C} \mathrm{min}^{-1}$, in order to obtain a crystalline and thermodynamically stable material. The resulting material was cooled and collected after $24 \mathrm{~h}$.

\section{Top-down processing}

Approximately $5 \mathrm{~g}$ of calcined material was added to $250 \mathrm{~mL}$ of a $1 \mathrm{~mol} / \mathrm{L}^{-1} \mathrm{NaOH}$ solution, being stirred for 50 minutes at $60^{\circ} \mathrm{C}$. The product obtained from this step consists of sodium silicate in water (equation 1).

$$
\mathrm{SiO}_{2}+2 \mathrm{NaOH} \rightarrow \mathrm{Na}_{2} \mathrm{SiO}_{3}+\mathrm{H}_{2} \mathrm{O}
$$


Subsequently, sodium silicate (brand, purity) was separated from the aqueous solution, to react with $200 \mathrm{~mL}$ of $1 \mathrm{~mol} / \mathrm{L}^{-1}$ hydrochloric acid (brand, purity) at $50{ }^{\circ} \mathrm{C}, 30-45 \mathrm{~min}$. The product obtained on a nanometric scale is presented by equation 2 (reaction of $\mathrm{Na}_{2} \mathrm{SiO}_{3}$ with $\mathrm{HCl}$, in the proportion $1: 2 \mathrm{v} / \mathrm{v}$.

$$
\mathrm{Na}_{2} \mathrm{SiO}_{3}+2 \mathrm{HCl} \rightarrow \mathrm{Nano} \mathrm{SiO}_{2}+2 \mathrm{NaCl}+\mathrm{H}_{2} \mathrm{O}
$$

\section{OBTANTION OF MAGNETIC NANOSILICA}

The magnetization of the nanosilica was carried out as described by Rhoden et al. (2017). For these reactions, $250 \mathrm{~mL}$ round-bottom flask containing $100 \mathrm{~mL}$ of ultrapure water previously deoxygenated was used, then $100 \mathrm{mg}$ of nanosilica and 100,500 or $1000 \mathrm{mg}$ of iron chloride II $\left(\mathrm{FeCl}_{2}\right)$ were added (Sigma-Aldrich ${ }^{\circledR}$ ) to promote the production of nanosilica with different amounts of $\mathrm{Fe}_{3} \mathrm{O}_{4}$ and ammonium hydroxide $\left(\right.$ Synth $\left.{ }^{\circledR}\right)$ until reaching an oxidizing $\mathrm{pH}(\mathrm{pH} \approx 9.0)$.

Afterwards, the mixture was submitted to ultrasonic radiation (Elma, power of $150 \mathrm{~W}$ ) for 60 minutes. Sequentially, the solution was poured with the assistance of a magnet, the solid was washed consecutively with methanol (Synth $\left.{ }^{\circledR}\right)$ and acetone (Synth $\left.{ }^{\circledR}\right)$. Subsequently, the material was dried (DeLeo) in an oven at $50{ }^{\circ} \mathrm{C}$ for total evaporation of solvents.

To obtain the magnetic nanosilica, nanosilica and $\mathrm{FeCl}_{2}$ were used and later, it was submitted to oxidation conditions. In equation (3), the methodology used to obtain the nanoparticle with magnetic properties is shown in a schematic way.

$$
\text { Nano } \mathrm{SiO}_{2}+\mathrm{FeCl}_{2} \rightarrow \text { Nano } \mathrm{SiO}_{2} \cdot \mathrm{Fe}_{3} \mathrm{O}_{4}
$$

\section{CHARACTERIZATION OF NANOPARTICLES FOURIER TRANSFORM INFRARED SPECTROSCOPY (FTIR)}

The equipment used to characterize the samples synthesized in this work was Perkin-Elmer FTIR, model Spectro One. The tablets were obtained with $2 \mathrm{mg}$ of sample and $200 \mathrm{mg}$ of the support $(\mathrm{KBr})$. The spectrum appears, in the form of bands, resulting from the vibrations of the molecules when absorbing infrared radiation (RHODEN, 2018).

\section{X-RAY DIFFRACTION (XRD)}

X-ray diffraction analyzes were performed using a Bruker diffractometer, model D2 Phaser. The samples were macerated and arranged in the sample holder so that they were as smooth as possible (RHODEN, 2018). 
The average size of the crystallite (D) is related to the half height of the diffracted peaks and the mesh parameter associated with the position of the peaks is given by equation (4) by Scherrer (1912):

$$
D_{h k l}=\frac{K \lambda}{\beta \cos \theta}
$$

Where $\mathrm{D}$ is the average crystallite size $(\mathrm{nm}), \mathrm{K}$ is the constant that depends on the shape of the particles, $\chi$ the wavelength of the electromagnetic radiation (nm), $\theta$ the diffraction angle $\left({ }^{\circ}\right)$ and $\beta$ the girth of the half peak height (FWHM). The degree of crystallinity of the samples was calculated using the reported method Navarro-Pardo et al. (2013) in equation (5), where Ac is the area of the crystalline peaks and $\mathrm{Aa}$ is the area of the amorphous cavities of the samples.

$$
\% C=\frac{A c}{A c+A a} \times 100
$$

\section{CYTOTOXIC ACTIVITY}

\section{Cell culture}

The cells were grown in polystyrene bottles (Corning) with Dubecco's Modified Eagle Medium (DMEM, Sigma-Aldrich), supplemented with 10\% Bovine Fetal Serum (Cultilab) and 1\% antibiotics (Penicillin/Streptomycin, Sigma-Aldrich ${ }^{\circledR}$ ) and incubated at $37{ }^{\circ} \mathrm{C}$ in a humidified $5 \%$ $\mathrm{CO}_{2}$ incubator. The culture media were replaced every 2-3 days, according to the metabolism of cell lines. Before reaching the confluence ( $70-80 \%$ of their saturation density), the cells were subjected to subculture to avoid eventual cell death due to excess cells.

The treatments of $1,5,10,25,50,100$ and $500 \mu \mathrm{g} / \mathrm{mL}^{-1}$ were established from results of the literature for the compound $\mathrm{SiO}_{2}$ (NABESHI et al., 2011; HANAFI-BOJD et al., 2017). L929 cells in the concentration of $1 \times 10^{4}$ cells well ${ }^{-1}$ received treatments for a period of 24 hours.

\section{3-(4,5-dimethylthiazol-2-yl)-2,5-diphenyltetrazolium bromide, a tetrazole) (MTT) assay}

The MTT test ([3- (4,5-dimethylthiazol-2yl)-2,5-diphenyl tetrazolium bromide]) is a colorimetric test used to assess cell viability. Dehydrogenases are enzymes present only in metabolically viable cells, they cleave the tetrazolium ring, transforming itself from a yellow-colored compound into a violet-colored compound, called formazan (MOSMANN, 1983). 
After 24 hours, a solution of $5 \mathrm{mg} \mathrm{mL}^{-1}$ of the reagent was prepared diluted in 1x fosfat buffered saline (PBS) (Prolab®) and subsequently added $20 \mu \mathrm{L}$ per well in the 96 well plates. After 4 hours of incubation in the $\mathrm{CO}_{2}$ oven, the supernatant was removed and add $200 \mu \mathrm{L}$ of dimethyl sulfoxide (DMSO) (Synth $\left.{ }^{\circledR}\right)$ to solubilize the crystals formed. Finally, the absorbance was read at a wavelength of $570 \mathrm{~nm}$.

\section{3-amino-7-dimethylamino-2-methylphenazine hydrochloride or neutral red assay}

The neutral red test was based on the initial protocol described by Borenfreund and Puerner (1985), following the methodology described by Fotakis and Timbrell (2006). This test is based on the cell's ability to absorb neutral red through endocytosis. The reagent is accumulated in the lysosomes of viable cells, thus being found in greater quantity in cells with integrity of the plasma membrane.

After 24 hours, the supernatant was removed and culture medium without serum was added fetal bovine with the neutral red reagent at a concentration of $40 \mu \mathrm{g} / \mathrm{mL}^{-1}$. It took 4 hours of incubation in the $\mathrm{CO}_{2}$ oven with the reagent in contact with the cells in the wells of the 96-well plate. Afterwards, the supernatant was removed, cells were washed with 1x PBS in order to remove excess unreacted reagent incorporated by them. Finally, a lysis solution containing 50\% ethanol (Synth®), 49\% distilled water and $1 \%$ acetic acid (Synth $\left.{ }^{\circledR}\right)$ for cell lysis and release of dye to read its absorbance at a wavelength of $540 \mathrm{~nm}$.

\section{Statistical analysis}

The analyzes were performed using the GraphPad Prism. To compare treatments, one-way analysis of variance (ANOVA) was performed, followed by Tukey's post hoc test. Statistically different values were considered with $\mathrm{P}<0.05 *, \mathrm{P}<0.01 * * \mathrm{P}<0.001 * * *$.

\section{RESULTS AND DISCUSSION}

FOURIER TRANSFORM INFRARED SPECTROSCOPY (FTIR)

Figure 1 shows the infrared spectra (FTIR) of the magnetite, nanosilica and magnetic nanosilica. 
Figure 1 - Infrared spectrum of magnetite, nanosilica and magnetic nanosilica.

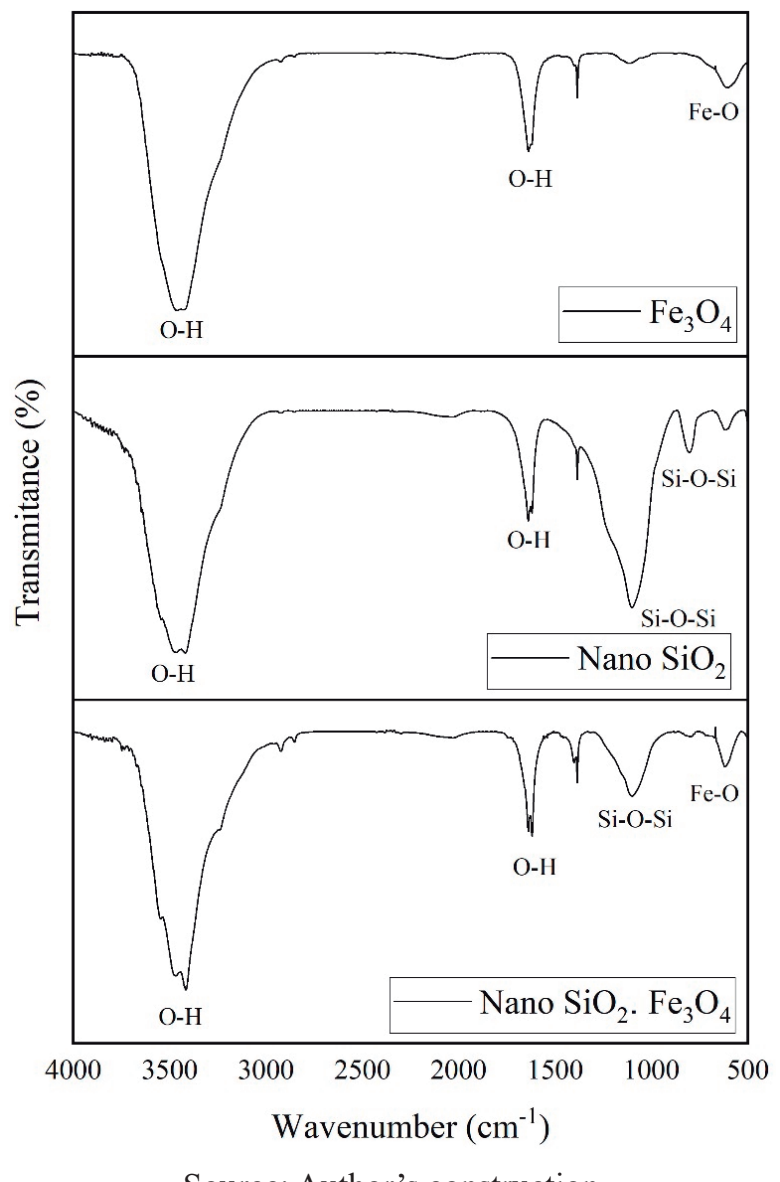

Source: Author's construction.

According to the Figure 1, In the FTIR spectrum of the nanosilica it was possible to observe a band in $801 \mathrm{~cm}^{-1}$ and another in $474 \mathrm{~cm}^{-1}$ indicating the symmetrical connection of $\mathrm{Si}-\mathrm{O}-\mathrm{Si}$ and in $1011 \mathrm{~cm}^{-1}$ the asymmetric vibration of the Si-O. In the spectrum of magnetic nanosilica, in addition to the peaks remaining constant, a more intense peak is seen around $600 \mathrm{~cm}^{-1}$ referring to $\mathrm{Fe}-\mathrm{O}$ binding indicating the incorporation of ferrite $\left(\mathrm{Fe}_{3} \mathrm{O}_{4}\right)$ in the nanomaterial (VENKATESWARAN; YUVAKKUMAR; RAJENDRAN, 2013; RHODEN et al., 2017). In addition, a band in the region of $3400 \mathrm{~cm}^{-1}$ and one in $1600 \mathrm{~cm}^{-1}$ was observed, attributed to the absorption of water molecules (YAZDIMAMAGHANI et al., 2013).

\section{X-RAY DIFFRACTION (XRD)}

Figure 2 shows the XRD referring the ferrite, magnetite, nanosilica and magnetic nanosilica, that demonstrate the characteristic peak of this structures. 
Figure 2 - X-ray diffractogram of magnetite, nanosilica and magnetic nanosilica.

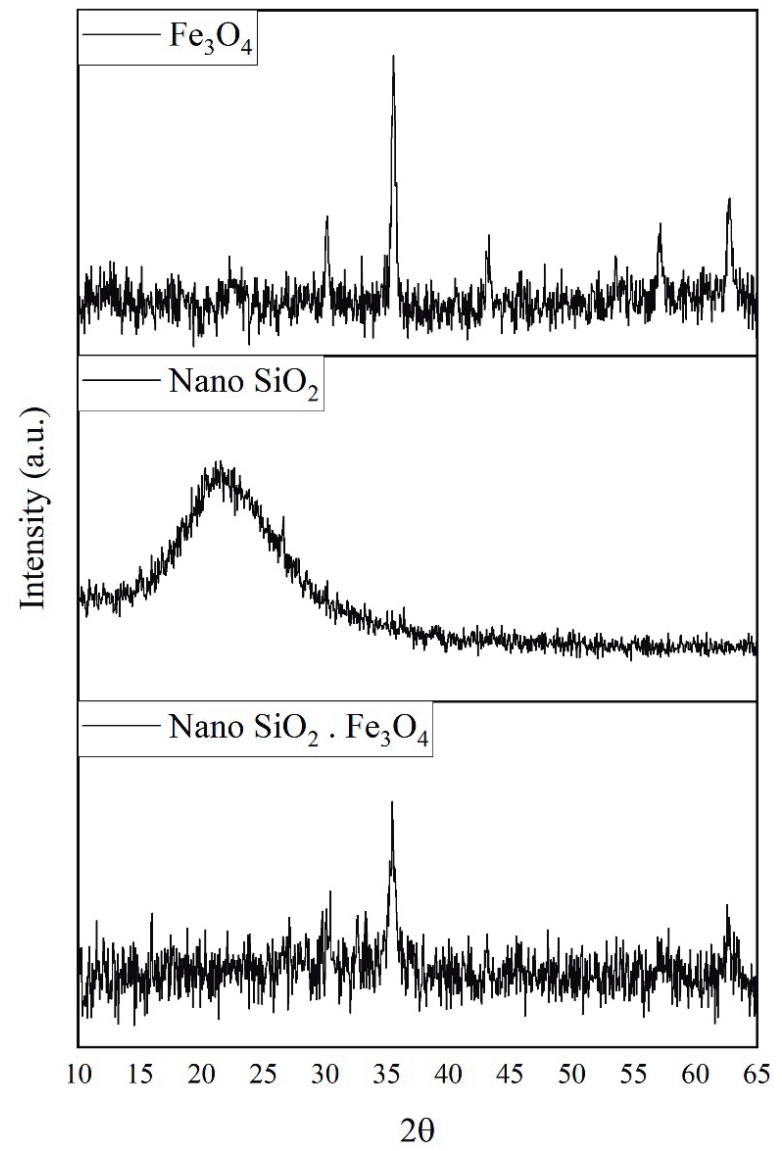

Source: Author's construction.

In the X-ray diffractogram (XRD) the amorphous structure of the synthesized material was observed, however, a characteristic peak of the nanosilica is seen at approximately $2 \Theta \approx 22^{\circ}$, attributed to cristobalite, a polymorphic form of the free nanosilica (NGUYEN et al., 2017). However, the XRD standard is expected for nanoparticles of silica purified with sodium hydroxide solution with low molarity (YUVAKKUMAR et al., 2014). About the XRD of magnetic nanosilica, the peak previously present at $2 \theta \approx 22^{\circ}$, was partially suppressed by the incorporation of ferrite observed at $2 \theta \approx 35^{\circ}, 45^{\circ}$, $57^{\circ}$ and $62^{\circ}$, confirming the obtaining of nano $\mathrm{SiO}_{2}$ with magnetic properties (RUÍZ -BALTAZAR et al., 2015; RHODEN et al., 2018).

Table 1 shows the percentages of crystallinity and the average crystallite size, calculated from equations 4 and 5 .

Table 1 - Degree of crystallinity of the samples and average crystallite size.

\begin{tabular}{ccc}
\hline Material & Degree of crystallinity (\%) & Average crystallite size (nm) \\
\hline${\mathrm{Nano} \mathrm{SiO}_{2}}_{\mathrm{Nano} \mathrm{SiO}_{2} \cdot \mathrm{Fe}_{3} \mathrm{O}_{4}}$ & 87.5 & 6.47 \\
$\mathrm{Fe}_{3} \mathrm{O}_{4}$ & 73.33 & 3.15 \\
\hline
\end{tabular}


According to the experimental data, it was found that the degree of crystallinity and particle size of the nanosilica decreased through the incorporation process. Changes in these parameters are expected, since, during the reaction, nanoparticles are subjected to high temperatures, highly oxidizing media and ultrasonic irradiation (RETAMAL MARÍN et al., 2018; ISLAM et al., 2014). The nanosilica and the magnetic nanosilica had a particle size like found by Silva et. al. (2017) who evaluated the luminescent and magnetic properties of the magnetic nanomaterials, with an average size around $8 \mathrm{~nm}$, also calculated by the Scherrer equation. Co-precipitation methodologies that use iron II salts are able to form precipitates with a smaller particle size. In addition, the temperature of the reaction medium and the use of ultrasonic energy accelerate the process of precipitate formation and prevent the disordered growth of nanoparticles (FREITAS et. al., 2015).

\section{CYTOTOXIC ACTIVITY}

\section{Colorimetric viability assay (MTT)}

Figure 3 represents the results of the MTT test after 24-hour treatment of L929 cells, at a concentration of $1 \times 10^{4}$ well $^{-1}$, cultured in a 96-well plate and treated with magnetic nanosilica with different concentrations and proportions of incorporated ferrite, in triplicates. From the concentration of $5 \mu \mathrm{g} / \mathrm{mL}^{-1}$, the cell viability rate decreases, in a dose-dependent manner, presenting statistical significance, as shown by the graph, in all dilutions of the compound.

Figure 3 - Cellular cytotoxicity of magnetic nanosilica with different proportions of incorporated ferrite.

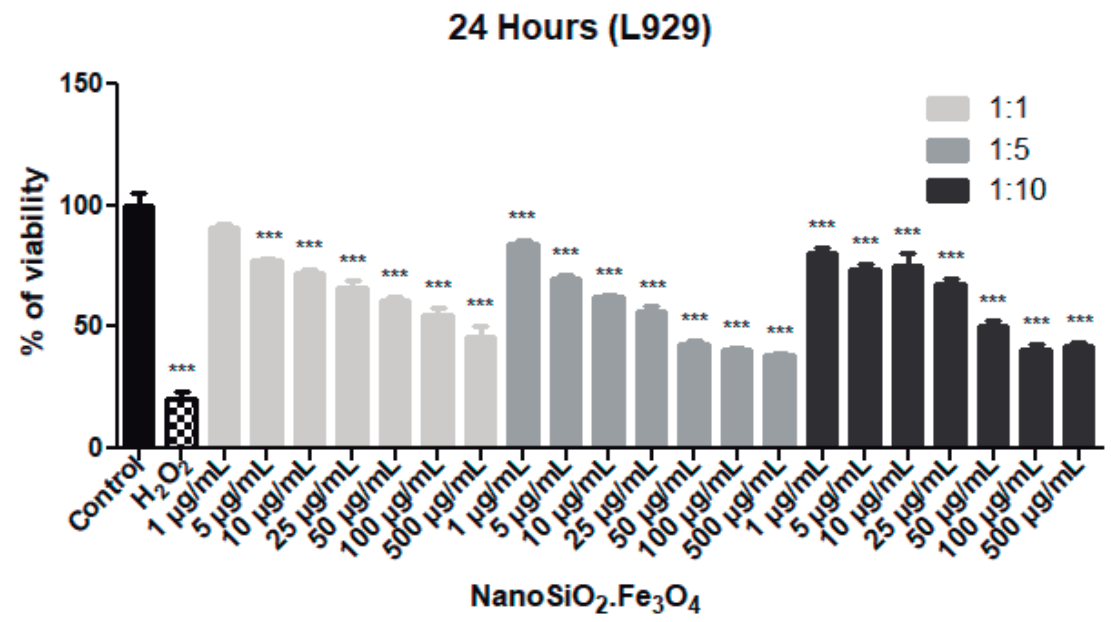

Legend: Data expressed as mean \pm standard deviation (SD). The analyzes were followed by one-way Anova, followed by Tukey's post hoc test, comparing the treatments with the negative control.

Values with $\mathrm{p}<0.05$ were considered statistically significant. Being $\mathrm{p}<0.05 *, * * \mathrm{p}<0.01 ; * * * \mathrm{p}<0.001$.

Colorimetric viability assay from the neutral red vital dye

Figure 4 represents the result of the cellular toxicity of the magnetic nanosilica by means of the neutral red colorimetric assay, under the same treatment conditions of the L929 cell line described in the cell culture item of the materials and methods assignment. For this assay it is possible to observe a significant decrease in the L929 cell line from the treatment with $50 \mu \mathrm{g} / \mathrm{mL}^{-1}$ of the magnetic 
nanosilica, in a dose-dependent manner, following the same behavior in all tested dilutions of the compound.

Figure 4 - Cellular cytotoxicity of magnetic nanosilica with different proportions of incorporated ferrite.

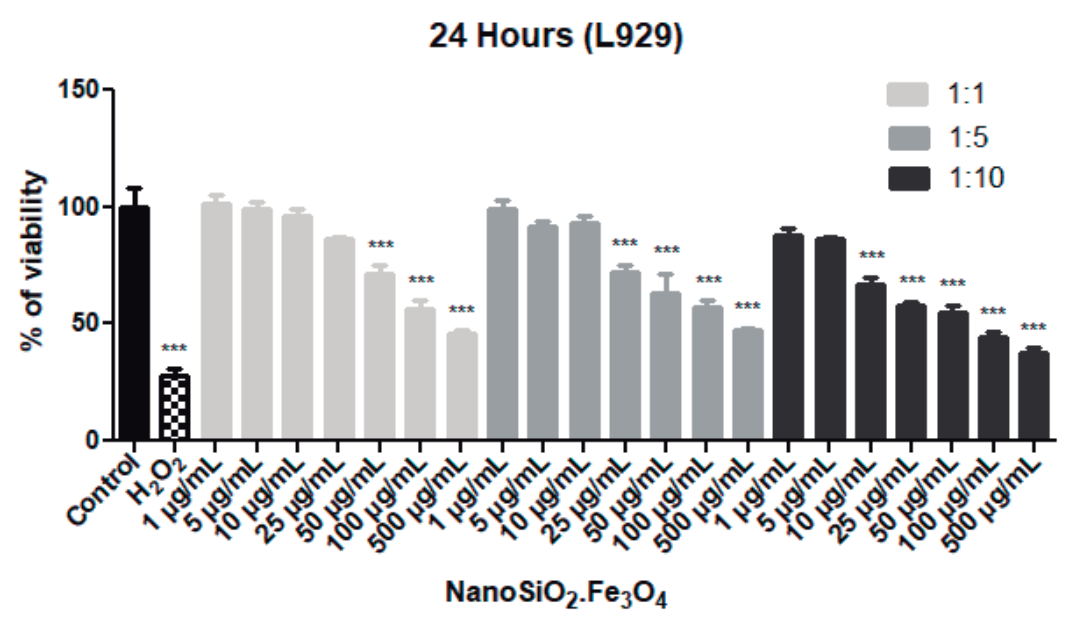

Legend: Data expressed as mean \pm standard deviation (SD). The analyzes were followed by one-way Anova, followed by Tukey's post hoc test, comparing the treatments with the negative control.

Values with $\mathrm{p}<0.05$ were considered statistically significant. Being $\mathrm{p}<0.05 *,{ }^{* *} \mathrm{p}<0.01 ;{ }^{* * *} \mathrm{p}<0.001$.

The evaluation of cytotoxicity was performed only in the 24-hour period, since longer periods aim to evaluate antiproliferative activity. Through the MTT assay it was found that only the concentration of $1 \mu \mathrm{g} / \mathrm{mL}^{-1}$ of the magnetic nanosilica in the proportion 1:1 proved to be safe in relation to the negative control, the other treatments showed a significant difference of $\mathrm{p}<0.001$. In all concentrations, cell viability ranged from $84 \%$ to $38.5 \%$ from the lowest to the highest concentration $\left(1-500 \mu \mathrm{g} / \mathrm{mL}^{-1}\right)$, with a 1:10 ratio similar behavior. Also, the concentration of $500 \mu \mathrm{g} / \mathrm{mL}^{-1}$ reduced the number of viable cells to $42 \%$. This results confirm a previous work, showing a concentrations dependence as well as incorporated iron/ferrite concentration (VIANA et al., 2019).

By the neutral red colorimetric assay, it is possible to observe that only the lowest tested concentrations of both compounds did not show a significant difference in relation to the negative control, again showing that, with the increase of $\mathrm{Fe}_{3} \mathrm{O}_{4}$ incorporated, the compound becomes more toxic for the cells. In the neutral red test, unlike MTT, the results show cytotoxicity from the concentration of $50 \mu \mathrm{g} / \mathrm{mL}^{-1}$, which reduced the number of cells to $71.5 \%$, reaching $46 \%$ in $500 \mu \mathrm{g} / \mathrm{mL}^{-1}$. In the ratio of $1: 5$, cytotoxicity was statistically present at a concentration of $25 \mu \mathrm{g} / \mathrm{mL}$, decreasing the number of cells to a level of $47 \%$ in $500 \mu \mathrm{g} / \mathrm{mL}^{-1}$. Finally, the 1:10 ratio showed a decrease in the number of viable cells from 10 to $500 \mu \mathrm{g} / \mathrm{mL}^{-1}$, with the percentage of live cells varying between 67 and 37.5 respectively (VIANA et al., 2019).

Guo et. al. (2015) investigated the cytotoxicity of $\mathrm{Fe}_{3} \mathrm{O}_{4}$, nano $\mathrm{SiO}_{2} \cdot \mathrm{Fe}_{3} \mathrm{O}_{4}$, in $\mathrm{L} 929$ cells. By the MTT assay they found that the increase in contact time and the concentration of nano $\mathrm{SiO}_{2} \cdot \mathrm{Fe}_{3} \mathrm{O}_{4}$ increased the observed cytotoxic effect. In addition, it was found that the functionalization of $\mathrm{Fe}_{3} \mathrm{O}_{4}$ 
with silica nanoparticles demonstrated a greater significant difference in cell viability, compared to pure ferrite.

The results found in this work corroborate also the studies carried out by Gupta and Wells (2004) that evaluated the cytotoxicity of magnetic nanoparticles in human fibroblasts. As the concentration of the nanoparticles increased, a significant loss in cell viability was observed by about 25-50\%. Dosedependent toxicity results were also observed by Park et. al. (2010), when evaluating the cytotoxicity of

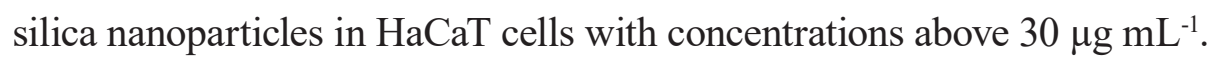

\section{ACKNOWLEDGMENT}

The authors would like to thank FAPERGS, CAPES and Universidade Franciscana-UFN for the scholarships granted.

\section{CONCLUSION}

Through the application of a fast, easy, and low energy methodology, nanosilica with magnetic properties was obtained, which can be evidenced by instrumental techniques of infrared spectroscopy and X-ray diffractogram, as well by approaching of an external magnetic field. It was also found that the incorporation of the magnetic nanoparticles caused changes in parameters such as average crystallite size and degree of crystallinity. The evaluation of cytotoxic activity carried out by MTT and neutral red colorimetric tests showed cell viability at low concentrations. However, increasing in the iron proportion and concentration increases the toxicity to cells. Further studies are necessary to furnish a complete security profile for biological applications.

\section{REFERENCES}

BARIK, T. K.; SAHU, B.; SWAIN, V. Nanosilica-from medicine to pest control. Parasitology Research, v. 103, n. 2, p. 253-258, 2008.

BEG, M. S. et al. Porous $\mathrm{Fe}_{3} \mathrm{O}_{4}-\mathrm{SiO}_{2}$ core-shell nanorods as high-performance MRI contrast agent and drug delivery vehicle. Journal of Magnetism and Magnetic Materials, v. 428, p. 340-347, 2017.

BORENFREUND, E.; PUERNER, J. A simple quantitative procedure using monolayer cultures for cytotoxicity assays (HTD/NR-90). Journal of Tissue Culture Methods, v. 9, p. 7-9, 1985. 
FOTAKIS, G.; TIMBRELL, J. In vitro cytotoxicity assays: comparison of LDH, neutral red, MTT and protein assay in hepatoma cell lines following exposure to cadmium chloride. Toxicology Letters, v. 2, p. 171-177, 2006.

FREITAS, J. C. de et al. Magnetic nanoparticles obtained by homogeneous coprecipitation sonochemically assisted. Materials Research, v. 18, p. 220-224, 2015.

GUO, X et al. Sulfhydryl-modified $\mathrm{Fe}_{3} \mathrm{O}_{4} @ \mathrm{SiO}_{2}$ core/shell nanocomposite: synthesis and toxicity assessment in vitro. ACS applied materials \& interfaces, v. 7, n. 27, p. 14983-14991, 2015.

GUPTA, A. K.; WELLS, S. Surface-modified superparamagnetic nanoparticles for drug delivery: preparation, characterization, and cytotoxicity studies. IEEE transactions on nanobioscience, v. 3, n. 1, p. 66-73, 2004.

HANAFI-BOJD, M. Y. MUC1 Aptamer-conjugated mesoporous silica nanoparticles effectively target breast cancer cells, Drug Development and Industrial Pharmacy, v. 44, p. 13-18, 2017.

ISLAM, M. T. et al. Preparation of nanocellulose: A review. AATCC Journal of Research,v. 1, n. 5, p. 17-23, 2014.

JANARDAN, S. et al. Assessment on the antibacterial activity of nanosized silica derived from hypercoordinated silicon (iv) precursors. RSC advances, v. 6, n. 71, p. 66394-66406, 2016.

LI, G. et al. Synthesis and characterization of $\mathrm{Fe}_{3} \mathrm{O}_{4} @ \mathrm{SiO}_{2}$ core-shell magnetic microspheres for extraction of genomic DNA from human whole blood. Journal of Nanoscience and Nanotechnology, v. 11, n. 12, p. 10295-10301, 2011.

MADHUMATHI, K. et al. Novel chitin/nanosilica composite scaffolds for bone tissue engineering applications. International Journal of Biological Macromolecules, v. 45, n. 3, p. 289-292, 2009.

MOSMANN, T. Rapid colorimetric assay for cellular growth and survival: application to proliferation and cytotoxicity assays. Journal of Immunological Methods, v. 65, p. 55-63, 1983.

NABESHI, H. et al. Systemic distribution, nuclear entry and cytotoxicity of amorphous nanosilica following topical application. Biomaterials, v. 32, p. 2713-2724, 2011. 
NAVARRO-PARDO, F. et al. Effects on the thermo-mechanical and crystallinity properties of nylon 6 , 6 electrospun fibres reinforced with one dimensional (1D) and two dimensional (2D) carbon. Materials, v. 6, n. 8, p. 3494-3513, 2013.

NGUYEN, N. T. et al. New oligochitosan-nanosilica hybrid materials: Preparation and application on chili plants for resistance to anthracnose disease and growth enhancement. Polymer Journal, v. 49, n. 12, p. 861-869, 2017.

ONG, H. R.; ISKANDAR, W. M. E.; KHAN, M. M. R. Rice Husk Nanosilica Preparation and Its Potential Application as Nanofluids. In: Silver Nanoparticles-Health and Safety. IntechOpen, 2019.

PARK, Y. et al. Assessment of dermal toxicity of nanosilica using cultured keratinocytes, a human skin equivalent model and an in vivo model. Toxicology, v. 267, n. 1-3, p. 178-181, 2010.

PINTO, C. G. et al. Development and study of the stability of nanostructured systems containing ginger oil. Disciplinarum Scientia Naturais e Tecnológicas, v. 18, n. 3, p. 515-529, 2017.

RETAMAL MARÍN, R. R. et al. Effects of sample preparation on particle size distributions of different types of silica in suspensions. Nanomaterials, v. 8, n. 7, p. 454, 2018.

RHODEN, C. R. B. et al. Síntese fácil e direta do Óxido de Grafeno Magnético. Disciplinarum Scientia, v. 18, n. 3, p. 389-397, 2017.

RHODEN, C. R. B. Síntese de análogos de peptídeos incorporados a materiais nanoparticulados de carbono funcionalizados via reações multicomponentes. 2018. 107 f. Tese de Doutorado (Doutor em Nanociências), Programa de Pós-Graduação em Nanociências, Universidade Franciscana, Santa Maria, RS, 2018.

RUÍZ-BALTAZAR, A. et al. Effect of the surfactant on the growth and oxidation of iron nanoparticles. Journal of Nanomaterials, v. 2015, p. 1-8, 2015.

SILVA, R. L. S. et al. Luminescent and magnetic properties of $\mathrm{Fe}_{3} \mathrm{O}_{4} @ \mathrm{SiO}_{2}$ : phen: $\mathrm{Eu}^{3+}$. Materials Research, v. 20, n. 5, p. 1317-1321, 2017.

SCHERRER, P. Bestimmung der inneren Struktur und der Größe von Kolloidteilchen mittels Röntgenstrahlen. In: Kolloidchemie Ein Lehrbuch. Springer, Berlin, Heidelberg, 1912. p. 387-409. 
VENKATESWARAN, S.; YUVAKKUMAR, R.; RAJENDRAN, V. Nano silicon from nano silica using natural resource (RHA) for solar cell fabrication. Phosphorus, Sulfur, and Silicon and the Related Elements, v. 188, n. 9, p. 1178-1193, 2013.

VIANA, A. R. et al. Cytotoxicity study of graphene oxide against vero lineage cells. Disciplinarum Scientia Naturais e Tecnológicas, v. 20, n. 3, p. 355-364, 2019.

VO, U. V. et al. Gelatin-poly (ethylene glycol) methyl ether-functionalized porous Nanosilica for efficient doxorubicin delivery. Journal of Polymer Research, v. 26, n. 1, p. 6, 2019.

YAZDIMAMAGHANI, M. et al. Synthesis and characterization of encapsulated nanosilica particles with an acrylic copolymer by in situ emulsion polymerization using thermoresponsive nonionic surfactant. Materials, v. 6, n. 9, p. 3727-3741, 2013.

YOSHIDA, T. et al. Promotion of allergic immune responses by intranasally-administrated nanosilica particles in mice. Nanoscale Research Letters, v. 6, n. 1, p. 1-6, 2011.

YUVAKKUMAR, R. et al. Rice husk ash nanosilica to inhibit human breast cancer cell line (3T3). Journal of Sol-Gel Science and Technology, v. 72, n. 1, p. 198-205, 2014.

ZHANG, W. et al. Preparation and application of mesoporous core-shell nanosilica using leucine derivative as template in effective drug delivery. Chinese Chemical Letters, v. 31, n. 5, p. 1165-1167, 2020. 